the enchanted wand of prosperity. The words commerce, merchant, market and mercury all come from the same Latin root, merx, mercis, goods, and mercor, to traffic; hence, this wand is appropriately placed on delivery cars, railway trains and steamships.

Green is not a medical color but has long been carried by the hospital; therefore, the green cross means nothing to the physician himself.

In mythology, history and sacred scripture, man has always considered the serpent as representing power, wisdom and health. Twined about the knotty rod it was associated with the statue of Esculapius at Epidaurus and became the earliest symbol of the healing art, as an expressive representation of power, support and protection in the difficult and knotty problems arising in the management of disease.

Scarlet and gold have always been regarded as characteristically medical colors. In the king's retinue, during occasions of state, the physician wore a scarlet cloak to distinguish him from the other professions. In the rural districts of Massachusetts a red flag was displayed from the farm house to notify the physician on his rounds that his services were required. In alchemy it is interesting to find that the philosopher's stone, when known as the elixir of life, was a red tincture, and as the key of wisdom, a red powder, and as a remedy for all diseases and to prolong human life, the alchemist mentions particularly a red stone.

Gold was spoken of by Gerber, the father of chemistry, who personified it as the "only pure and healthy man," and it was made the symbol of the sun, which orb had the greatest influence over disease.

These elements of the knotty rod and serpent, with scarlet and gold, have been embraced in the device of a simple emblem for the medical profession and accepted by the American Medical Association; hence, it is a mistake to persuade the doctor to wear a commercial badge, but he should be taught throughout the country, in the Army as well as in civil practice, to carry one correct and uniform design.

Further particulars and explanations can be found in THE Journal, April 24, 1909, p. 325; the Red Cross Bulletin, July, 1909, p. 40, and New York Medical Journal, May 30, 1914.

Samuel P. Gerhard, A.M., M.D., Philadelphia.

[COMMENT.-It has been frequently contended that the wand of Mercury is not the proper symbol for the medical profession, as it has no medical significance; in fact, its adoption by the Army Medical Corps might be considered a reflection on the interest which we, as a nation, take in things classical. If the question is asked why the wand of Mercury was ever adopted as the symbol of the Medical Corps, the reply is rather difficult; surely not because the caduceus was used by Mercury as conductor of the souls of the dead to the world below. As pointed out by McCulloch (Military Surgeon, 41:137 [Aug.] 1917), the emblem may have been borrowed originally from the Public Health Service, in which it had been used for many years. Churchill, the London medical publisher, used it on title pages two generations ago; but whoever recommended its use as a medical emblem in this country has either been conducted by Mercury, his titular deity, to join the souls of the dead in the world below, or is keeping unusually quiet.

However, the English are also said to have fallen into the same error. McCulloch tells us that the first use of the caduceus in medical heraldry was doubtless in the crest of Henry VIII's physician, the learned Sir William Butts-the same Sir William who appears in Shakespeare's drama of Henry VIII (V, ii, 11) :

$$
\begin{aligned}
& \text { 'Tis Butts, } \\
& \text { Cranmer [Aside.] } \\
& \text { The King's physician; as he past along, } \\
& \text { How earnestly he cast his eyes upon me. }
\end{aligned}
$$

The Greek poets refer to Hermes or Mercury as giving sleep with the magic wand to whomsoever he chose; hence Milton calls the wand "his opiate rod," in Paradise Lost, $\mathrm{xi}, 133$. Also Erasmus Darwin (grandfather of Charles Darwin) in Loves of the Plants, ii, 291, says :

So, with his dread caduceus, Hermes led

From the dark regions of the imprisoned dead

Or drove in silent shoals the lingering train

To Night's dull shore and Pluto's dreary reign.

Such allusions as these may have given rise to the false conception of Mercury and caused the reader to suppose that if he could wave the "opiate rod" he could administer medica- ments as well. Be that as it may, the first use of the caduceus by the Medical Department of our army was on the chevron of the uniform of the hospital steward, in 1856, although it was not employed by the medical officers until 1902 .

As for the staff and serpent of Esculapius: There is no doubt that this is a much more appropriate emblem for the medical profession than the wand of Mercury. It may be interesting to note that this emblem is now worn by the Royal Army Medical Corps.

Those who believe that preventive medicine is the crowning glory of the profession, as it certainly would seem to be, at this time, might prefer as an emblem, Hygeia (the goddess of health and the daughter of $Æ$ sculapius), surrounded by symbols representing her close companions-air, water, light, food, exercise, sleep, etc. Thus we should have the culmination of the trinity composed of Apollo, the sun-god and the very ancient god of medicine; Asculapius, considered to be the son of Apollo; and the beautiful daughter of Esculapius -Hygeia-at whose shrine perhaps more of the medical profession of today would be willing to worship than at the shrine of Æsculapius.-ED.]

\section{“THE NEEDS OF MEDICAL EDUCATION AS REVEALED BY THE WAR"}

To the Editor:- I have read with a great deal of interest the article on medical education by Munson, in the last number of The Journal, and also an editorial and the letters of Vaughan and Munson, and I am writing to you to suggest that in any statistical study made by the Surgeon-General in regard to medical reserve officers it would be of interest to know :

1. The number of graduates of each medical school that were commissioned.

2. The number from each medical school that were discharged from the service prior to November 11, for any reason.

3. The number of graduates of every medical school living Nov. 11, 1918.

The first two items, of course, could only be supplied by the Surgeon-General's Office, while the latter, I imagine could be readily supplied by THE Journal if the Hollerith system was used for the directory.

The subdividing of the discharges under the head of different causes would be of interest, although, I believe, would give a mistaken impression, as there was a tendency I noted to "deal lightly" in regard to discharges, and thus many discharges for physical disability might well and properly have been included under other headings.

GoRDon WILson, M.D., Baltimore.

\section{IDENTITY OF THE POPPY IN FLANDERS' FIELDS}

To the Editor:-In the late Surgeon McCrae's poem "In Flanders' Fields," prominent mention is made of poppies in bloom, and local discussion has arisen as to whether they are of the variety that yields opium; and if so, whether there is not a deeper sense, almost therapeutic, in the words : "We shall not sleep though poppies grow in Flanders' field."

If this is Papaver somniferum, why is the world supply of opium drawn from Asiatic sources, and why may not the plant be cultivated successfully in America for therapeutic purposes? Or was the allusion in the verses merely an example of poetic license?

George Homan, M.D., St. Louis.

[COMMENT.-It seems possible that the line in MacCrae's poem "We shall not sleep though poppies blow in Flanders' fields" was written advisedly. No doubt the poppies that grow in Flanders' fields are Papaver rhoeas, red poppy, or corn poppy. The capsules yield a milky juice, and an extract has been prepared having the properties of opium. The effect is very feeble, however, and the plant is of value mainly for its scarlet coloring matter.

The poppy which yields opium is Papaver somniferum and is generally believed to be a native of Asia Minor. It grows wild in southern Europe and even in England. It is successfully cultivated for its opium content in India, China, Japan Asiatic Turkey, and other places. In Europe and the United States it is cultivated for its seeds, which yield a fixed oil. -ED.]. 